\title{
Revisiting the Link between Trade Openness and Economic Growth Using Panel Methods
}

Abdul Jalil ( $\nabla$ jalil.hanif@gmail.com )

Nazia Bibi

Pakistan Institute of Development Economics

\section{Research}

Keywords: Trade Openness, Economic Growth, Panel Methods, Cross-sectional Dependence, CCEMG, GMM

Posted Date: May 21st, 2020

DOl: https://doi.org/10.21203/rs.3.rs-29499/v1

License: () (1) This work is licensed under a Creative Commons Attribution 4.0 International License. Read Full License

Version of Record: A version of this preprint was published at The Journal of International Trade \& Economic Development on June 13th, 2021. See the published version at https://doi.org/10.1080/09638199.2021.1938638. 


\section{Abstract}

The link between trade openness and economic growth remains an open question due to the inconclusive findings provided by empirical studies. We argue that the primary reasons for such inconclusive findings are the differences between previous studies regarding their methodologies, samples of countries, measures of trade openness, and duration of analyses. Based on this argument, we reinvestigate the trade-growth nexus through newly developed methodologies for five different subsamples from 1960 to 2017. This study also integrates a robust sample of 82 countries and employs different measures of trade openness. The econometric results support the idea that trade openness induces economic growth. These findings emerge after applying a variety of panel data specifications to the data, including a common correlated effects mean group (CCEMG) estimator and a generalized method of moments (GMM) estimator, which allows for endogeneity between trade and growth. The findings of the study challenge previous empirical results that indicate that trade restrictions promote economic growth. Based on our findings, we can safely claim that trade openness may contribute to economic growth.

\section{Background}

The impact of trade openness on economic performance is an extensively discussed issue in the economics literature. The literature on international trade provides three theories regarding the effects of international trade on economic growth. First, the Ricardian-Heckscher-Ohlin model postulates that trade may cause a one-time increase in output due to a comparative advantage but will have no long-term impact on international trade. Second, neoclassical growth theory posits that technological change is exogenous and, therefore, that the trade policy of a country does not affect its economic performance. Third, new growth theories suggest that continuously increasing trade openness leads to the adoption of new technologies, thus allowing an open economy to grow faster than a closed economy.

The empirical literature extensively analyzes the impact of international trade on economic growth (see Table 1). The central question that these analyses aim to answer is whether international trade affects long-term economic growth. The answers are inconclusive, as three separate theories have been put forth. 
Table 1

Summary of Trade-Growth Nexus of Cross-Country Analysis

\begin{tabular}{|c|c|c|c|c|}
\hline Authors & $\begin{array}{l}\text { Time } \\
\text { Coverage }\end{array}$ & $\begin{array}{l}\text { Econometric } \\
\text { Methodology }\end{array}$ & Country Coverage & Causal Relationship \\
\hline $\begin{array}{l}\text { Jung and } \\
\text { Marshall (1985) }\end{array}$ & $\begin{array}{l}1950- \\
1981\end{array}$ & Granger Causality & $\begin{array}{l}37 \text { Developing } \\
\text { Countries }\end{array}$ & $\begin{array}{l}\text { There is no link between trade and growth except. However, } \\
\text { Indonesia, Costa Rica, Egypt and Ecuador are exceptions. }\end{array}$ \\
\hline Chow (1987) & $\begin{array}{l}1960- \\
1985\end{array}$ & Sims' Causality Test & $\begin{array}{l}08 \text { Newly } \\
\text { Industrializing } \\
\text { Countries }\end{array}$ & Positive Impact of Trade on Economic Outcomes \\
\hline Dollar (1992) & $\begin{array}{l}1976- \\
1985\end{array}$ & OLS Regression & $\begin{array}{l}95 \text { Developing } \\
\text { Countries }\end{array}$ & Positive Impact of Trade on Economic Outcomes \\
\hline Edwards (1992) & $\begin{array}{l}1970- \\
1982\end{array}$ & OLS Regression & $\begin{array}{l}30 \text { Developing } \\
\text { Countries }\end{array}$ & Positive Impact of Trade on Economic Outcomes \\
\hline $\begin{array}{l}\text { Levine and Renelt } \\
\text { (1992) }\end{array}$ & $\begin{array}{l}1960- \\
1989\end{array}$ & OLS Regression & 119 Countries & Positive Impact of Trade on Economic Outcomes \\
\hline Lee (1993) & $\begin{array}{l}1960- \\
1985\end{array}$ & OLS regression & 108 Countries & Positive Impact of Trade on Economic Outcomes \\
\hline Yaghmaian(1994) & $\begin{array}{l}1971- \\
1991\end{array}$ & OLS regression & 66 Countries & Positive (Partially) Impact of Trade on Economic Outcomes \\
\hline O'Rourke (2000) & $\begin{array}{l}1875- \\
1913\end{array}$ & OLS with Fixed Effect & $\begin{array}{l}10 \text { Developed } \\
\text { Countries }\end{array}$ & Positive Impact of Trade on Economic Outcomes \\
\hline Yanikkaya (2003) & $\begin{array}{l}1970 \text { to } \\
1997\end{array}$ & $\begin{array}{l}\text { Cross Country } \\
\text { Regression }\end{array}$ & 100 Countries & $\begin{array}{l}\text { trade to growth in developing countries and trade barriers to } \\
\text { growth }\end{array}$ \\
\hline $\begin{array}{l}\text { Dowrick and } \\
\text { Golley (2004) }\end{array}$ & $\begin{array}{l}1960- \\
2000\end{array}$ & OLS Regression & 124 Countries & Positive Impact of Trade on Economic Outcomes \\
\hline Rassekh (2007) & $\begin{array}{l}1960- \\
1985\end{array}$ & $\begin{array}{l}\text { OLS and Instrumental } \\
\text { Variable }\end{array}$ & 150 Countries & Positive Impact of Trade on Economic Outcomes \\
\hline $\begin{array}{l}\text { Chang and Ying } \\
\text { (2008) }\end{array}$ & $\begin{array}{l}1970- \\
2002\end{array}$ & $\begin{array}{l}\text { Fully Modified Ordinary } \\
\text { Least Square }\end{array}$ & $\begin{array}{l}\text { Economic Commission } \\
\text { for Africa }\end{array}$ & Positive Impact of Trade on Economic Outcomes \\
\hline Foster (2008) & $\begin{array}{l}1960- \\
2003\end{array}$ & Quantile Regression & $\begin{array}{l}75 \text { Liberalizing } \\
\text { Countries }\end{array}$ & Trade to Growth and No Impact in Low Developing Countries \\
\hline $\begin{array}{l}\text { Economidou and } \\
\text { Murshid (2008) }\end{array}$ & $\begin{array}{l}1978- \\
1997\end{array}$ & $\begin{array}{l}\text { OLS and GMM } \\
\text { regression }\end{array}$ & 12 OECD countries & Positive Impact of Trade on Economic Outcomes \\
\hline $\begin{array}{l}\text { Kneller et al. } \\
(2008)\end{array}$ & $\begin{array}{l}1970- \\
1998\end{array}$ & Fixed Effect Regression & $\begin{array}{l}37 \text { Liberalizing } \\
\text { Countries }\end{array}$ & Positive Impact of Trade on Economic Outcomes \\
\hline $\begin{array}{l}\text { Buch and Toubal } \\
(2009)\end{array}$ & $\begin{array}{l}1991- \\
2004\end{array}$ & $\begin{array}{l}\text { OLS and Fixed Effect } \\
\text { Panel Regression }\end{array}$ & $\begin{array}{l}\text { East and West } \\
\text { Germany }\end{array}$ & Positive Impact of Trade on Economic Outcomes \\
\hline $\begin{array}{l}\text { Chang et al. } \\
(2009)\end{array}$ & $\begin{array}{l}1960- \\
2000\end{array}$ & GMM Methodology & $\begin{array}{l}20 \text { Developed and } 60 \\
\text { Developing Countries }\end{array}$ & Positive Impact of Trade on Economic Outcomes \\
\hline Gries et al. (2009) & $\begin{array}{l}1960- \\
1980\end{array}$ & $\begin{array}{l}\text { Hsiao's Granger } \\
\text { Causality }\end{array}$ & $\begin{array}{l}16 \text { Sub-Saharan } \\
\text { Countries }\end{array}$ & $\begin{array}{l}\text { Cointegration evidence shows that growth and trade do not share } \\
\text { long run relationship }\end{array}$ \\
\hline $\begin{array}{l}\text { Dufrenot et al. } \\
\text { (2010) }\end{array}$ & $\begin{array}{l}1980- \\
2006\end{array}$ & Quantile Regression & $\begin{array}{l}75 \text { developing } \\
\text { countries }\end{array}$ & Heterogeneous trade growth nexus \\
\hline Kim et al (2011) & $\begin{array}{l}1960- \\
2000\end{array}$ & $\begin{array}{l}\text { instrumental variable } \\
\text { threshold regressions }\end{array}$ & 61 Countries & Positive Impact of Trade on Economic Outcomes \\
\hline Rao et al. (2011) & $\begin{array}{l}1974- \\
2004\end{array}$ & $\begin{array}{l}\text { Non Linear Two Stage } \\
\text { Least Square }\end{array}$ & 5 Asian Countries & Positive Impact of Trade on Economic Outcomes \\
\hline Tekin (2012) & $\begin{array}{l}1970- \\
2009\end{array}$ & $\begin{array}{l}\text { Panel Granger } \\
\text { Causality Test }\end{array}$ & 18 Least Developed & Positive Impact of Trade on Economic Outcomes \\
\hline $\begin{array}{l}\text { Menyah et al. } \\
\text { (2014) }\end{array}$ & $\begin{array}{l}1965- \\
2008\end{array}$ & $\begin{array}{l}\text { Heterogeneous Panel } \\
\text { Methods }\end{array}$ & 21 African Countries & Positive Impact of Trade on Economic Outcomes \\
\hline $\begin{array}{l}\text { Cooray et al. } \\
(2014)\end{array}$ & $\begin{array}{l}1970- \\
2008\end{array}$ & GMM Methodology & South Asian countries & Positive Impact of Trade on Economic Outcomes \\
\hline $\begin{array}{l}\text { Ramanayake and } \\
\text { Lee }(2015)\end{array}$ & $\begin{array}{l}1980- \\
2009\end{array}$ & $\begin{array}{l}\text { POLS, Fixed Effect, } \\
\text { GMM }\end{array}$ & 205 countries & Nonlinear relations between Trade and Growth \\
\hline $\begin{array}{l}\text { Pradhan et al. } \\
\text { (2017) }\end{array}$ & $\begin{array}{l}1961- \\
2012\end{array}$ & Panel Cointegration & ASEAN Countries & Positive Impact of Trade on Economic Outcomes \\
\hline $\begin{array}{l}\text { Cooray et al. } \\
(2017)\end{array}$ & $\begin{array}{l}1985- \\
2012\end{array}$ & GMM Methodology & $\begin{array}{l}48 \text { Sub-Saharan } \\
\text { Countries }\end{array}$ & Positive Impact of Trade on Economic Outcomes \\
\hline
\end{tabular}




\begin{tabular}{|lllll|}
\hline Authors & $\begin{array}{l}\text { Time } \\
\text { Coverage }\end{array}$ & $\begin{array}{l}\text { Econometric } \\
\text { Methodology }\end{array}$ & Country Coverage & Causal Relationship \\
\hline $\begin{array}{l}\text { Mullings and } \\
\text { Mahabir (2018) }\end{array}$ & $\begin{array}{l}1990- \\
2009\end{array}$ & Fixed Effect and GMM & African Countries & Positive but non-robust outcomes. \\
\hline $\begin{array}{l}\text { Ramzan et.al } \\
(2019)\end{array}$ & $\begin{array}{l}1990- \\
2014\end{array}$ & GMM & 82 countries & Nonlinear relations between Trade and Growth \\
$\begin{array}{l}\text { Manwa et al } \\
(2019)\end{array}$ & $1980-$ & Fixed Effect & $\begin{array}{l}\text { Southern African } \\
\text { Customs Union } \\
\text { countries }\end{array}$ & Positive Impact of trade on Economic outcomes \\
\hline
\end{tabular}

\begin{tabular}{|c|c|c|c|c|c|c|c|c|c|c|}
\hline & Pooled OLS & & & CCEMG & & & GMM & & & CCEMG \\
\hline Regressors & 1 & 2 & 3 & 4 & 5 & 6 & 7 & 8 & 9 & 10 \\
\hline \multirow[t]{2}{*}{ Trade } & 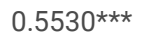 & - & - & $0.4406^{*}$ & - & - & $0.6343^{\star \star}$ & - & - & 0.6591 \\
\hline & $(0.0361)$ & - & - & (0.2339) & - & - & $(0.2797)$ & - & - & $(0.2663$ \\
\hline \multirow[t]{2}{*}{ Tariff } & - & $-0.5121^{*}$ & - & - & $-0.8010 * * *$ & - & - & $-0.6493^{* * *}$ & - & - \\
\hline & - & $(0.2970)$ & - & - & $(0.2666)$ & - & - & $(0.2589)$ & - & - \\
\hline \multirow[t]{2}{*}{ Glob } & - & - & $0.6826^{\star \star \star}$ & - & - & $0.8525^{\star \star \star}$ & - & - & $0.2723^{*}$ & - \\
\hline & - & - & $(0.1410)$ & - & - & $(0.2975)$ & - & - & $(0.1476)$ & - \\
\hline \multirow[t]{2}{*}{ K } & $0.4305^{\star \star}$ & $0.1904^{\star \star \star}$ & $0.2304^{\star \star \star}$ & $0.3584^{\star \star *}$ & $0.7025^{\star \star \star}$ & $0.5906^{\star *}$ & $0.8291 *$ & $0.4140 \star \star \star *$ & $0.8619 * *$ & $0.6018^{y}$ \\
\hline & $(0.1913)$ & $(0.0423)$ & $(0.0794)$ & $(0.1361)$ & $(0.2548)$ & $(0.2527)$ & $(0.4970)$ & (0.1588) & $(0.3878)$ & (0.2345 \\
\hline \multirow[t]{2}{*}{ FD } & $0.3245^{\star \star}$ & $0.5395^{\star \star \star}$ & $0.3990 * \star *$ & $0.5352^{\star \star *}$ & $0.4045^{\star \star \star}$ & $0.1621^{*}$ & $0.1548 * \star \star$ & $0.4689 *$ & $0.3242^{\star \star}$ & $0.7928^{\prime}$ \\
\hline & $(0.1463)$ & $(0.1035)$ & (0.1269) & $(0.1530)$ & $(0.0385)$ & $(0.0954)$ & $(0.0204)$ & $(0.2781)$ & $(0.1476)$ & (0.1616 \\
\hline \multirow[t]{2}{*}{$\mathrm{CPI}$} & $-0.6842^{\star \star \star}$ & $-0.2946 * \star \star$ & $-0.2664^{\star}$ & $-0.4377 *$ & $-0.0651^{\star \star *}$ & $-0.6824^{\star}$ & 0.5743 & 0.6267 & 0.4081 & -0.3817 \\
\hline & $(0.2778)$ & $(0.0472)$ & $(0.1333)$ & $(0.2412)$ & (0.0107) & $(0.3612)$ & $(0.4855)$ & $(0.4730)$ & $(0.2782)$ & (0.2306 \\
\hline \multirow[t]{2}{*}{ EDU } & $0.6388^{\star \star \star}$ & 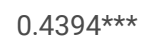 & $0.6886^{* \star *}$ & $0.3933^{\star \star \star}$ & $0.2517^{\star \star \star}$ & $0.3109 * *$ & $0.8177^{* \star \star}$ & $0.5845^{\star \star}$ & $0.4818^{*}$ & 0.1229 \\
\hline & $(0.2629)$ & $(0.1024)$ & $(0.1669)$ & $(0.1458)$ & $(0.0980)$ & $(0.1506)$ & $(0.1980)$ & $(0.2612)$ & $(0.2718)$ & $(0.0579$ \\
\hline \multirow[t]{2}{*}{ GOV } & $0.8350 \star \star \star *$ & $0.4262^{\star \star}$ & 0.9064 & $0.7047^{\star *}$ & 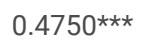 & $0.7051^{\star \star \star}$ & $0.4869 *$ & $0.8390 \star \star \star *$ & $0.7251^{\star \star \star}$ & $0.3626^{\prime}$ \\
\hline & $(0.1406)$ & (0.1957) & $(0.7680)$ & $(0.2997)$ & (0.1970) & $(0.2018)$ & $(0.2745)$ & $(0.1945)$ & $(0.2550)$ & (0.1501 \\
\hline \multirow{2}{*}{$\begin{array}{l}\text { Dependent } \\
\text { lag }\end{array}$} & - & - & - & - & - & - & 0.7633 & 0.5636 & 0.6833 & $0.3173^{y}$ \\
\hline & - & - & - & - & - & - & $(0.5217)$ & $(0.7912)$ & $(0.6081)$ & $(0.0273$ \\
\hline \multirow[t]{2}{*}{ constant } & 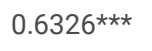 & $0.7944^{\star \star \star}$ & 0.8641 & $0.8211^{\star}$ & $0.6889 \star \star \star$ & $0.5208^{\star \star \star}$ & $0.8233^{*}$ & $0.7631^{\star \star \star *}$ & 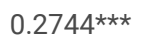 & $0.3437^{\prime}$ \\
\hline & (0.1997) & $(0.1548)$ & $(0.7656)$ & $(0.5353$ & $(0.2752)$ & $(0.1858)$ & $(0.4369)$ & $(0.2740)$ & $(0.0701)$ & $(0.0659$ \\
\hline \multicolumn{11}{|l|}{ Diagnostics } \\
\hline$N$ & 4560 & 4560 & 4560 & 4560 & 4560 & 4560 & 4560 & 4560 & 4560 & 4560 \\
\hline $\begin{array}{l}\text { No. of } \\
\text { Instrument }\end{array}$ & - & - & - & - & - & - & 207 & 207 & 207 & 207 \\
\hline Sargan & - & - & - & - & - & - & 0.3622 & 0.4714 & 0.2819 & 0.5893 \\
\hline Hansen-J & - & - & - & - & - & - & 0.1610 & 0.6567 & 0.4924 & 0.4523 \\
\hline$C D$ & - & - & - & 50.7638 & 46.1682 & 47.6613 & - & - & - & 50.763\{ \\
\hline$p$-value & - & - & - & 0.0000 & 0.0008 & 0.0001 & - & - & - & 0.0000 \\
\hline $\begin{array}{l}\text { Country } \\
\text { Fixed } \\
\text { Effect }\end{array}$ & YES & YES & YES & YES & YES & YES & YES & YES & YES & YES \\
\hline $\begin{array}{l}\text { Time Fixed } \\
\text { Effect }\end{array}$ & YES & YES & YES & YES & YES & YES & YES & YES & YES & YES \\
\hline
\end{tabular}




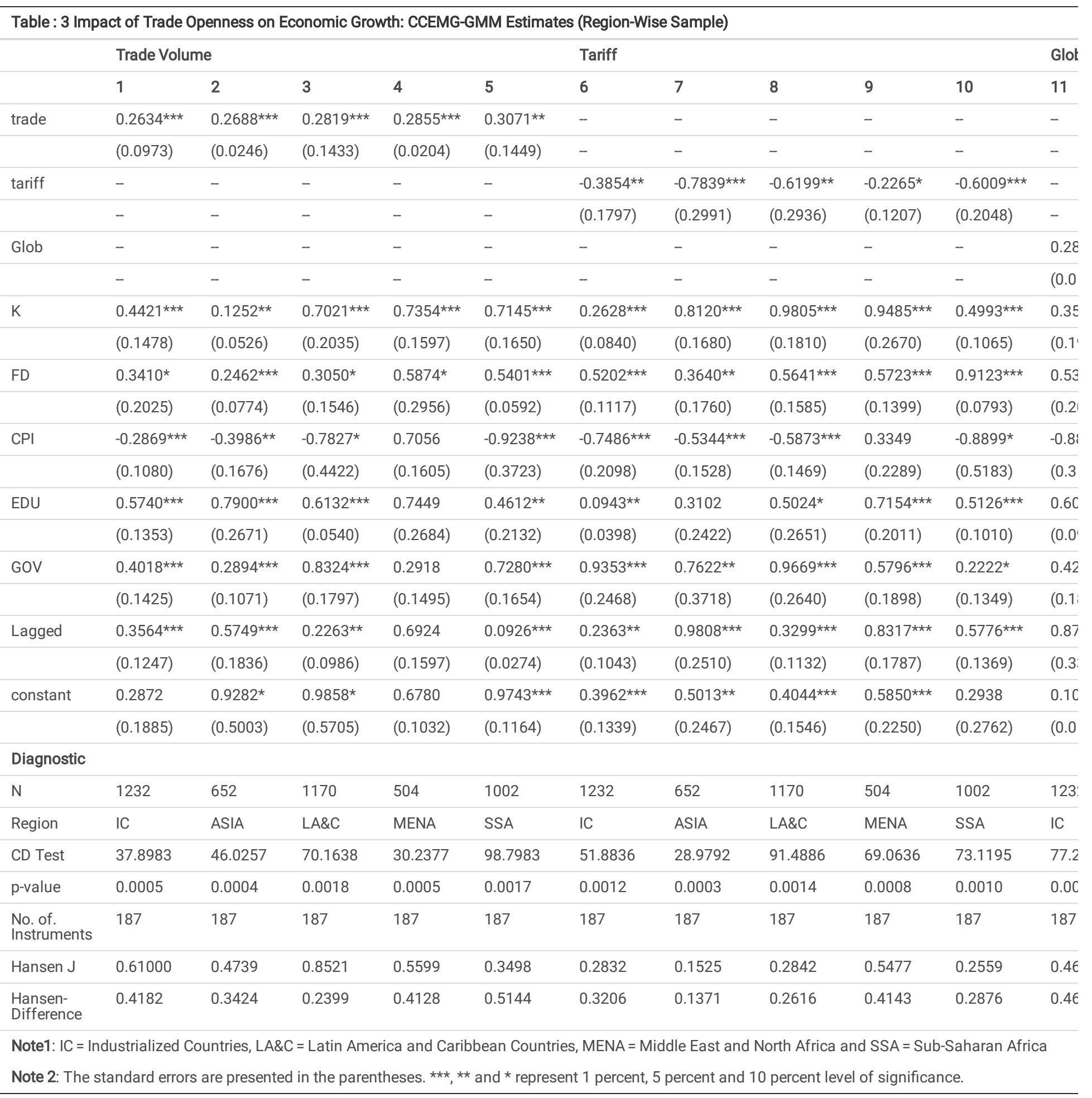

\section{Methodology And Econometric Issues}

Much of the literature documents that trade volumes have positive effects on economic growth. However, the impact of trade policies is controversial. On the one hand, lowering trade barriers can reduce the economic cost of production. On the other hand, there is a consensus among researchers that lowering trade barriers could negatively impact the performance of industries and, in turn, the economic growth of countries. This controversy motivates us to investigate the nexus further. With this controversy in mind, we can specify a trade-growth nexus model using the following framework:

$y=f($ open $Z)$

(1)

where $y$ is the natural log of per capita gross domestic product (GDP), open represents the various measures for trade openness, and $Z$ represents control variables. Several studies have extended this function in response to particular research questions and in light of various theoretical backgrounds. However, the primary foundation of the function remains the same. For example, financial sector development is the most-often discussed factor in the context of the 
trade-growth nexus. Specifically, Misati and Nyamongo (2012) utilized the measure of financial sector development in their growth regression. Similarly, Lloyd and MacLaren (2000) and Jin (2006) have focused on foreign direct investment and trade volumes as crucial factors of economic growth. Buch and Toubal (2009) consider physical capital as a determinant of economic growth through the theory of international trade, (i.e., comparative advantage).

Following Yanikkaya (2003), we specify the following econometric equation to investigate the relationship between economic growth and trade openness:

$$
\Delta y_{i t}=\alpha_{0}+\alpha_{1} o p e n_{i t}+\alpha_{2} k_{i t}+\alpha_{3} f d_{i t}+\alpha_{4} c p i_{i t}+\alpha_{5} e d u_{i t}+\alpha_{5} g o v_{i t}+u_{i t}
$$

where $\Delta y$ is change in the log of GDP per capita; open is a proxy for trade openness which is further divided into trade volumes, tariff policy, and a general index of globalization; $\mathrm{k}$ is the natural log of real per capita capital; cpi is a measure of inflation; fd denotes financial development; edu is used as a measure of human capital; and gov is governance.

There may be at least two sources of bias in Eq. 2 (cross-sectional dependence bias and endogeneity bias).

Importantly, much of the openness-growth nexus ignores the issue of cross-sectional dependence, causing a downward bias in standard errors. The presence of cross-sectional dependence across the panel of countries is crucial due to the high degree of financial integration and globalization in the breakthrough of international trade. Therefore, a shock affecting any country within the panel may affect other countries in the panel. Therefore, the presence of economic interdependence through trade requires to test the level of cross-sectional dependence by using Pesaran's (2004) cross-sectional dependence test. We use CCEMG when the null hypothesis related to cross-sectional independence is rejected. CCEMG is proposed by Pesaran (2006) to address cross-sectional dependence and heterogeneity.

The other sources of bias in Eq. 2 are related to endogeneity bias. Endogeneity bias may arise due to omitted variables and simultaneity, which are very common in single equation growth regressions. There are several ways to avoid endogeneity bias. We utilize a system GMM estimation because of its favorable properties. GMM has gained popularity among researchers for several reasons. For example, Nickell (1981) documents that GMM estimators can provide solutions for several issues (e.g., fixed effects, endogeneity, lack of external instruments, short panel bias, and dynamic panel bias). Furthermore, GMM estimators can handle unbalanced panels and multiple endogenous variables.

It is important to ensure that the empirical results are not influenced by cross-sectional dependence and endogeneity. Therefore, these issues should be addressed together. For this purpose, following Chudik and Pesaran (2015) and Neal (2015), we use CCEMG-GMM by using the lags of endogenous variables to account for cross-sectional dependence and endogeneity. CCEMG manages the endogeneity that can arise due to common factors and reverse causation. However, to ensure that our results are reliable, we estimate a CCE equation for each country using GMM. The simple average of the slope parameters will provide CCEMG-GMM.

\section{Empirical Findings And Discussion}

The estimation process is conducted in several steps. Specifically, we estimate Eq. 2 using different estimators to account for cross-sectional dependence and endogeneity for the panel of 82 countries from 1960 to 2017 . The natural start of the estimation process is to estimate Eq. 2 through ordinary least squares (OLS). This regression controls for country-fixed effects and time-fixed effects. The results from such a regression serve as baseline results. Then, we estimate the regression through CCEMG to address the issue of cross-sectional dependence and through GMM to deal with endogeneity. After this, CCEMG-GMM is estimated to address cross-sectional dependence and endogeneity jointly. In addition, several diagnostic tests are performed to test the statistical health of the regressions.

The findings for the full sample are presented in Table 2. The first three columns (i.e., columns 1, 2, and 3) of Table 2 depict the results of the pooled ordinary least square (POLS) estimator. The results are based on a priori expectations. However, we do not discuss the result of the POLS due to the bias inherited from endogeneity and cross-sectional dependence. The lower panel of columns 4, 5, and 6 of Table 2 portray the cross-sectional dependence (CD) statistics and pvalues. Based on the p-values, the null hypothesis is rejected regarding the cross-sectional independence among the panels. This implies that POLS estimates provide biased results. Therefore, we use CCEMG as an alternative. The upper panel of columns 4, 5, and 6 of Table 2 shows the CCMEG estimates.

The first CCMEG regression, which regresses trade, $k, f d, c p i$, edu, and gov on log difference of per capita GDP, is estimated. Denoted by trade (the natural log of trade-to-GDP ratio) is the trade dependency ratio (column 4, Table 2). This is the sum of the exports and imports of goods and services measured as a share of GDP. The value of , which is the coefficient of trade openness, is positive and significant. This implies that trade volumes enter significantly positively in the growth regression.

The economic implication of this finding is that an increase in international trade in terms of trade volumes may lead to an increase in the economic growth of a country. This finding is in line with, for example, Chang et al. (2009), Rao et al. (2011), Cooray et al. (2014), Cooray et al. (2017), and Zahonogo (2017). However, the findings presented in other studies (e.g., O'Rourke, 2000; Gries et al., 2009) are not consistent with our findings. However, a country's trade dependency ratio and trade volume do not reflect its political stance. It is postulated that several economic developments (e.g., exchange rate dynamics, technological regress) and other macroeconomic fluctuations may be reflected in trade volumes. Therefore, we look at other proxies for trade openness that indicate a country's stance in terms of trade policies. Furthermore, as mentioned earlier, the impacts of trade liberalization and trade policies are more controversial than the influence of trade volume in terms of economic impact. 
We think that tariff rates are a direct indicator of trade openness and serve as an accurate policy-related variable. However, different studies on the tradegrowth nexus define and measure tariff rates in different ways. Two noteworthy studies are mentioned presently. First, effective tariff rate (i.e., the ratio of tariff revenue to total import revenue) is used by Kanbur and Zhang (2005), while average tariff rate is considered by Dobson and Ramlogan (2009). Ma and Dei (2009) note that these measures of tariff rates could have different impacts on the economic outcomes of a country. Therefore, it is worthwhile to use multiple measures of tariff rates in an analysis. Doing so will provide more accurate information regarding the impact of trade liberalization on economic growth than using one measure alone.

Thus, we use multiple measures of tariff rates but do not see any ambiguous findings in the cross-country analysis. Therefore, we present our results in terms of average tariff rates to make comparisons easier between our results and those of notable previous studies (see columns $2,5,8$, and 11, Table 2 ).

The average tariff rate enters significantly negatively in the growth regression. This trend implies that the trade policy of reducing restrictions has a positive impact on economic growth. The statistically significant negative sign implies that the economic growth of developing countries could be enhanced by reducing the average tariff rate. Specifically, economic growth could increase by 0.8010 percent due to a 1-percent decrease in tariff rates. Our results corroborate the findings of Wacziarg and Welch (2008), Kneller et al. (2008), and Gries et al. (2009).

The use of tariffs as a proxy of trade openness has been criticized on various grounds despite having the appropriate trade policy dimensions. For example, some aggregation biases exist, especially in the case of average tariff rates. Furthermore, there are significant gaps between statutory tariff rates and the collected tariffs, especially in developing countries. In addition, Dollar and Kraay (2004) note that there is little correlation between the measures of trade volume and tariff rates. Therefore, trade volumes and trade policy measures might yield misleading results in terms of economic growth.

Keeping these problems in view, we incorporate a third proxy measure of trade openness, (i.e., the globalization index of Dreher et al. (2008)). This index gives proper weights to trade volumes and tariff rates, as well as to other flow and restriction measures of trade openness. Therefore, it should be considered a more comprehensive measure than trade volume and average tariff rate. The information provided in columns $3,6,9$, and 12 of Table 2 shows that the measure of globalization enters significantly positively in the growth regression. This confirms our finding that trade openness has a positive impact on economic growth in the cross-country analysis.

As mentioned earlier, there are other variables besides trade openness that may affect economic growth. Such variables are incorporated in our study so that the relationship between trade openness and economic growth will not be spurious. For this purpose, we select a few variables (e.g., capital series, financial development, inflation, human capital, and governance), as has been done in most of the literature on endogenous growth. The construction of these variables is mentioned in the appendix.

Table 2 shows that physical capital has a positive impact on economic growth for all three specifications. This outcome is in line with a large portion of the literature that states that investment activities and physical capital stocks have a positive impact on economic growth. Human capital and physical capital are of great importance in the discussion of endogenous growth theories. We also incorporate a measure of human capital, which enters significantly positively in the growth regression. This finding supports the most highly accepted endogenous growth theory.

Recently, financial sector development has received special attention in two dimensions. First, it has been discovered that a well-functioning financial system could enhance the economic growth of countries (Jalil et al., 2010) and that trade-growth could flourish via various channels of financial sector development (Baltagi et al., 2009). Therefore, a measure of financial sector development must be incorporated into a growth regression. By including such a measure, we show that financial sector development has a positive impact on economic growth in the cross-country analysis. Inflation is another variable that should be discussed in the context of the trade-growth nexus. The findings of the current paper suggest that inflation hurts economic growth. However, these parameters are statistically insignificant in almost all cases.

Second, the quality of institutions is an important explanatory variable discussed in the recent literature. Acemoglu et al. (2001), among others, provide evidence that the quality of institutions explains the differences among countries in terms of economic growth. However, there is no consensus in the literature as to how the quality of institutions should be measured. For example, it can be measured through law and order, the quality of formal institutions, the corruption and accountability of public officials, and many other factors. Therefore, we develop an index (denoted GOV) by using a principal component analysis (see the appendix). The regression result is in line with those of distinguished studies. That is, it is found that the quality of institutions has a positive impact on economic growth. However, we contradict the findings of Rodrik et al. (2004) and Rigobon and Rodrik (2005), who state that trade openness enters negatively in the growth regression when it is restricted by institutions and geography.

Further, we distribute the sample of countries into five subsamples (see Appendix A). We replicate the exercise on each of these subsamples with alternative measures of trade openness. That is, we estimate CCEMG and GMM for each of the five subsamples. Interestingly, trade openness does not alter the sign in these subsamples. We address two methodological issues - cross-sectional dependence and endogeneity. These can be addressed individually using a CCMEG estimator and a GMM estimator. So far, we are convinced that the positive impact of trade openness on GDP growth is not derived from crosssectional dependence or endogeneity. However, jointly addressing these issues could be enlightening.

For this purpose, following Chudik and Pesaran (2015) and Neal (2015), we use CCEMG-GMM by using the lags of endogenous variables. The estimation results are shown in Table 2 (for the full sample) and Table 3 (for the region-wise analysis). The signs and significance levels are not changed considerably by combining the CCEMG and GMM. This implies that our main results are not affected by endogeneity or cross-sectional dependence. As such, empirical studies that have shown that trade openness has either a negative impact or no impact on economic activities should be reconsidered.

We have estimated the impact of trade openness on economic growth through four estimators. The estimates are similar in terms of their economic interpretations (i.e., the signs of the coefficients). However, interestingly, the sizes of the coefficients of the CCEMG-GMM estimations are much smaller than

Page $7 / 10$ 
those of any other estimator. The coefficients range from 0.2634 to 0.3071 for CCEMG-GMM. Therefore, we suspect that the CCEMG-GMM estimates might be affected by endogeneity and cross-sectional dependence.

Interestingly, the findings derived from the CCEMG-GMM are very close to the findings of Lewer and Berg (2003), who suggest that a 1-percent improvement in trade openness results in an increase in economic growth of around 0.2 percent.

Our estimated models pass various diagnostic tests (see the lower panels of Tables 2 and 3). We restrict the estimation by up to two lags. We perform the Sargan test and autocorrelation test to verify the validity of the instruments used in our study. The p-values of the tests show that the instruments are valid, and the $p$-values of Hansen and difference-in-Hansen tests signify the appropriateness of the instruments. Specifically, the p-values of significantly less than one imply that there is no issue of instrument proliferation.

\section{Conclusion}

This article revisits the trade-growth nexus using heterogeneous panel methods that consider cross-sectional dependence and endogeneity in several subsamples of countries from 1960 to 2017 . This article contributes to the existing literature on the trade-growth nexus in several ways. First, it considers several measures of trade openness to test the trade-growth nexus. Second, this article addresses two important methodological issues (i.e., cross-sectional dependence and endogeneity) and addresses these issues jointly using various estimators. Finally, the findings for different regions are presented.

The findings of this article support the view of trade-led growth portrayed in the literature. Importantly, these results are robust when alternative estimators are used. Therefore, we can safely conclude that different countries' levels of trade openness explain differences in their economic growth. Furthermore, we contradict the idea that restrictions on trade promote economic growth. Some authors have made such an argument to motivate the protectionist policy measures being undertaken in some emerging economies. Our estimates suggest that trade restrictions are likely to hamper the economic growth of countries that have already begun to boost their economic growth. Therefore, policymakers are encouraged to implement trade policies based on lower tariffs to attract trade and investment opportunities.

Our findings are robust regarding several econometric issues that can arise in long panel data (e.g., cross-sectional dependence and endogeneity). Therefore, studies that postulate that trade restrictions favor economic activity should be revised in light of these econometric issues, as their findings could be affected by cross-sectional dependence and endogeneity.

In addition, other control variables (e.g., physical capital, human capital, financial development, and the quality of institutions) are found to be statistically significant in the regressions, and the corresponding results are consistent with the theory. These findings challenge the existing empirical results reported in the literature.

Our findings provide a clear message to policymakers that more trade openness can bolster the economic performance of countries. Furthermore, reductions of trade restrictions through free trade agreements are expected to help countries to improve their economies. Other factors, such as physical capital, human capital, financial sector development, and the quality of institutions, also play essential roles in economic growth.

Though the findings of this study are straightforward and useful for policymakers, our panel covers several decades, and many events have occurred during this period. Therefore, researchers could investigate whether the impact of trade has varied between smaller periods within the period of 1960 to 2017 . An analysis of this nature could provide meaningful insights. Furthermore, there is a serious need for an empirical study to shed light on the robust findings of the trade-growth nexus and the channels through which trade impacts countries' economic performance.

\section{Declarations}

Author Contributions: The idea of this paper is conceptualized by Abdul Jalil (A.J) and Nazia Bibi (N.B.). Then methodology is devised by A.J. and N.B. the software is used by A.J.; the findings are validated by N.B. The formal analysis, investigation and original draft is initiated by A.J. While data collection, review and editing are done by A.J. and N.B. The entire work is supervised by A.J. In nut shell, both authors contributed equally. All authors have read and agreed to the published version of the manuscript.

Funding: This study is not funded by any agency.

Conflicts of Interest: WE declare that there is not conflict of interest

Availability of Data : The datasets used and/or analysed during the current study are available from the corresponding author on reasonable request.

Acknowledgment: My thanks to Hamad Manzoorfor for editorial assistance through the project. Errors of course remain the responsibility of the authors.

\section{References}

1. Acemoglu D, Simon J, Robinson JA (2001) The colonial origins of comparative development: An empirical investigation. Am Econ Rev 91:1369-1401

2. Alcala F, Ciccone A (2004) Trade and productivity. Q J Econ 119:613-646

3. Archibugi D, Michie J (1998) Technical Change, Growth and Trade: New Departures in Institutional Economics. J Economic Surveys 12:313-332

4. Baltagi BH, Demetriades PO, Law SH (2009) Financial development and openness: Evidence from panel data. J Dev Econ 89:285-296

5. Buch CM, Toubal F (2009) Openness and growth: The long shadow of the Berlin Wall. J Macroecon 31:409-422

Page $8 / 10$ 
6. Cadot O, Carrere C, Strauss-Kahn V (2013) Trade Diversification, Income, and Growth: What Do We Know? J Economic Surveys 27:790-812

7. Chang CP, Ying YH (2008) The generative power of air freight in the trade openness economic growth nexus in African countries. South African Journal of Economics 76:493-512

8. Chang R, Kaltani L, Loayza NV (2009) Openness can be good for growth: The role of policy complementarities. J Dev Econ 90:33-49

9. Chow PCY (1987) Causality between export growth and industrial development: empirical evidence from newly industrialized countries. J Dev Econ 28:265-276

10. Chudik A, M. H. and Pesaran (2015) Common Correlated Effects Estimation of Heterogeneous Dynamic Panel Data Models with Weakly Exogenous Regressors. J Econ 188:393-420

11. Chui M, Levine P, Murshed SM, Pearlman J (2002) North-South Models of Growth and Trade. J Economic Surveys 16:123-165

12. Cooray A, Mallick S, Dutta N (2014) Gender-specific human capital, openness and growth: exploring the linkages for South Asia. Rev Dev Econ 18:107122

13. Cooray A, Dutta N, Mallick S (2017) Trade openness and labor force participation in Africa: The role of political institutions. Industrial Relations 56:319350

14. Dobson S, Ramlogan ,C (2009) Is there an openness Kuznets curve? Kyklos 62:226-238

15. Dollar D (1992) Outward-oriented developing economies really do grow more rapidly: Evidence from 95 LDCs, 1976-1985. Econ Dev Cult Change 40:523544

16. Dollar D, Kraay A (2004) Trade, growth, and poverty. Econ J 114(493):F22-F49

17. Dowrick S, Golley J (2004) “Openness and growth: Who benefits?”. Oxf Rev Econ Policy 20:38-56

18. Dreher A, Gaston N, and Martens. P (2008) Measuring globalization: gauging its consequences. Springer, New York

19. Dufrenot G, Mignon V, Tsangarides C (2010) The trade-growth nexus in the developing countries: a quantile regression approach. Review of World Economics 146:731-761

20. Economidou C, Murshid AP (2008) Testing the linkages between trade and productivity growth. Rev Dev Econ 12:845-860

21. Edwards S (1992) Trade orientation, distortions, and growth in developing countries. J Dev Econ 39:31-57

22. Foster $N$ (2008) The impact of trade liberalisation on economic growth: Evidence from a quantile regression analysis. Kyklos 61:543-567

23. Frankel J, Romer D (1999) “Does trade cause growth?”. Am Econ Rev 89(3):379-399

24. Gries T, Kraft M, Meierrieks D (2009) Linkages between financial deepening, trade openness, and economic development: causality evidence from SubSaharan Africa. World Dev 37:1849-1860

25. Greenaway D, Morgan W, Wright P (2002) Trade liberalisation and growth in developing countries. J Dev Econ 67:229-244

26. Jalil A, Feridun M, Ma Y (2010) Finance-growth nexus in China revisited: New evidence from principal components and ARDL bounds tests. International Review of Economics Finance 19:189-195

27. Jin C (2006) Can openness be an engine of sustained high growth rates and inflation? Evidence from Japan and Korea. Int Rev Econ Finance 15:228-240 28. Jung WS, Marshall PJ (1985) Exports, growth and causality in developing countries. J Dev Econ 18:1-12

29. Kanbur R, Zhang X (2005) Fifty years of regional inequality in China: A journey through revolution, reform and openness. Rev Dev Econ 9:87-106

30. Kim DH, Lin SC, Suen YB (2011) Nonlinearity between trade openness and economic development. Rev Dev Econ 15:279-292

31. Kneller R, Morgan CW, Kanchanahatakij S (2008) Trade liberalization and economic growth. World Econ 31:701-719

32. Levine R, Renelt D (1992) A sensitivity analysis of cross-country growth regressions. Am Econ Rev 82:942-963

33. Lewer JJ, Berg VH (2003) “How Large Is International Trade's Effect on Economic Growth?”. J Economic Surveys 17:363-396

34. Lloyd PJ, MacLaren D (2000) Openness and growth in East Asia after the Asian crisis. Journal of Asian Economies 11(1):89-105

35. Lopez RA (2005) Trade and Growth: Reconciling the Macroeconomic and Microeconomic Evidence. J Economic Surveys 19:623-648

36. Ma Y, and Dei. F (2009) Product quality, wage inequality, and trade liberalization. Rev Int Econ 17:244-260

37. Manwa F, Wijeweera A, Kortt MA (2019) Trade and growth in SACU countries: A panel data analysis. Econ Anal Policy 63:107-118

38. Menyah K, Saban N, Yemane WR (2014) Financial development, trade openness and economic growth in African countries: New insights from a panel causality approach. Econ Model 37:386-394

39. Misati RN, Nyamongo EM (2012) Financial liberalization, financial fragility and economic growth in SSA. Journal of Financial Stability 8:150-160 40. Mullings R, Mahabir A (2018) Growth by Destination: The Role of Trade in Africa's Recent Growth. World Dev 102:243-261

41. Neal T (2015) The unbiased estimation of heterogeneous coefficients in panel data models with common factors and feedback effects (Mimeo). University of New South Wales, Sydney

42. Nickell S, J (1981) Biases in dynamic models with fixed effects. Econometrica 49:1417-1426

43. O'Rourke KH (2000) Tariffs and growth in the late 19th century. Econ J 110:456-483

44. Pesaran M (2004) "General diagnostic tests for cross section dependence in panels." IZA Discussion Papers 1240, Institute for the Study of Labor (IZA) 45. Pesaran MH (2006) Estimation and inference in large heterogeneous panels with multifactor error structure. Econometrica 74:967-1012

46. Pradhan RP, Arvin MB, Hall JH,, Nair M (2017) Trade openness, foreign direct investment, and finance-growth nexus in the Eurozone countries. The Journal of International Trade Economic Development 26:336-360 
47. Ramanayake SS, Lee K (2015) Does openness lead to sustained economic growth? Export growth versus other variables as determinants of economic growth. J Asia Pac Econ 20(3):345-368

48. Ramzan M, Sheng B, Shahbaz M, Song J and Zhilun Jiao (2019) Impact of trade openness on GDP growth: Does TFP matter? The Journal of International Trade Economic Development 28(8):960-995

49. Rao BB, Arthur T, Chaitanya. VK (2011) Growth effects of a comprehensive measure of globalization with country specific time series data. Appl Econ 43:551-568

50. Rassekh F (2007) Is international trade more beneficial to lower income economies? An empirical inquiry. Rev Dev Econ 11:159-169

51. Redding S (1999) Dynamic comparative advantage and the welfare effects of trade. Oxf Econ Pap 51:15-39

52. Rigobon R, Rodrik D (2005) Rule of law, democracy, openness, and income. Econ Transit 13:533-564

53. Rodrik D, Subramanian A, and Trebbi. F (2004) Institutions rule: The primacy of institutions over geography and integration in economic development. J Econ Growth 9:131-165

54. Rodríguez F, Rodrik D (2000) Trade policy and economic growth: A skeptic's guide to the cross-national evidence. NBER Macroeconomics Annual 15:261325

55. Squalli J, and Wilson. K (2011) A new measure of trade openness. The World Economy 34:1745-1770

56. Tekin RB (2012) Economic growth, exports and foreign direct investment in Least Developed Countries: A panel Granger causality analysis. Econ Model 29:868-878

57. Wacziarg R, Welch KH (2008) "Trade liberalization and growth new evidence. The World Bank Economic Review 22:187-231

58. Winters LA, Masters A (2013) Openness and Growth: Still an Open Question? J Int Dev 25:1061-1070

59. Yaghmaian B (1994) An empirical investigation of exports, development, and growth in developing countries: Challenging the neoclassical theory of export-led growth. World Dev 22:1977-1995

60. Yanikkaya $\mathrm{H}$ (2003) Trade openness and economic growth: A cross-country empirical investigation. J Dev Econ 72:57-89

61. Young A (1991) Learning by doing and the dynamics effects of international trade. Quart J Econ 106:369-405

62. Zahonogo P (2017) Trade and economic growth in developing countries: Evidence from Sub-Saharan Africa. Journal of African Trade 3:41-56

\section{Supplementary Files}

This is a list of supplementary files associated with this preprint. Click to download.

- Appendices.docx 